\title{
ABSTRAK \\ PERANAN PROGRAM PNPM-MANDIRI PEDESAAN DALAM MENDORONG PARTISIPASI DAN PEMBERDAYAAN MASYARAKAT LOKAL
}

\author{
Usman Matdoan, Dosen STIA Darul Rachman Tual, Maluku \\ 085243478643, E-mail: upagusman@ gmail.com
}

\begin{abstract}
Kehadiran Program Nasional Pemberdayaan Masyarakat (PNPM) Mandiri Pedesaan sejak dalam perjalanannya telah mendorong dan menciptakan pemberdayaan serta tumbuh dan berkembangnya tingkat partisipasi masyarakat lokal dalam setiap tahapan pembangunan, program ini telah memposisikan masyarakat sebagai aktor atau pelaku utama dalam proses pembangunan.
\end{abstract}

Kata kunci: pemberdayaan, partisipasi

\author{
ABSTRACT \\ THE ROLE OF THE PNPM MANDIRI-RURAL PROGRAM \\ IN ENCOURAGING THE PARTICIPATION AND EMPOWERMENT \\ OF LOCAL COMMUNITIES
}

\begin{abstract}
The presence of National Community Empowerment Program (PNPM) Independent Country since in his travels has been encouraging and creating empowerment as well as growing and growing level of partisipasition local communities in each stage of development, this program has been positioning the community as the main actor or actors in the development process.
\end{abstract}

Keywords: participation, empowerment

\begin{tabular}{|c|c|}
\hline $\begin{array}{l}\text { unan nasioanal dalam konsep } \\
\text { isasi dan desentralisasi telah }\end{array}$ & $\begin{array}{c}\text { konsep yang } \\
\text { gkan ketika orang berk }\end{array}$ \\
\hline
\end{tabular}


Pemerintah, Swasta, LSM maupun oleh Masyarakat itu sendiri.

Permberdayaan dan partisipasi adalah merupakan persoalan utama dalam pendeketan pambangunan yang terpusat pada masyarakat dan berkesinambungan serta merupakan proses interaktif yang berkelanjutan. Prinsip dasar dalam proses pemberdayaan dan partisipasi adalah melibatkan atau peran serta masyarakat secara langsung, dan hanya mungkin dapat dicapai jika masyarakat ikut ambil bagian sejak dari awal, proses sampai dengan perumusan hasil. Keterlibatan masyarakat akan menjadi jaminan bagi suatu proses yang baik dan benar. Oleh Abe (2005) mengasumsikan bahwa proses pemberdayaan dan partisipasi menyebabkan masyarakat telah terlatih secara baik. Menurutnya tanpa adanya prakondisi dalam arti mengembangkan teknik dan ketrampilan tertentu maka keterlibatan masyarakat secara langsung tidak akan memberikan manfaat yang banyak.

Lebih lanjut Abe

(2005) mengemukakan bahwa, keterlibatan masyarakat secara langsung dalam pembangunan akan membawa dampak penting, yakni: (1) Terhindar dari peluang terjadinya manipulasi, keterlibatan masyarakat akan memperjelas apa yang sebenarnya dikehendaki oleh masyarakat; (2) Memberikan nilai tambah pada legitimasi rumusan perencanaan karena semakin banyak jumlah mereka yang terlibat akan semakin baik; dan (3) Meningkatkan kesadaran dan ketrampilan politik masyarakat.

Wacana pembangunan yang partisipatif di Indonesia sesungguhnya telah dilakukan sejak lama, dimana konsep pembangunan dari rakyat, oleh rakyat dan untuk rakyat telah dimasukan dalam GBHN pada dekade 1970-an. Sementara kebijakan yang lebih konkrit dimulai sejak dekade tahun 1980-an selanjutnya sejak dekade 1990-an, kegiatan pembangunan di daerah lebih partisipatif melalui lembaga pengambilan keputusan mulai dari tingkat Desa, Kecamatan, Kebupaten, Propinsi sampai pada tingkat Nasional (Siregar, 2001). Akan tetapi menurut Team Work Lapera (2001) pada saat itu partisipasi masyarakat lebih sebagai jargon pembangunan, di mana partisipasi lebih diartikan pada bagaimana upaya mendukung program pemerintah dan upaya pelaksanaannya. 
Namun demikian dari beberapa dasar apapun dapat menumbuhkan perkembangan selanjutnya terdapat kecemburuan dan mendorong terjadinya berbagai model dan bentuk partisipasi konflik sosial di masyarakat. Melalui yang benar-benar dapat mengakomodasi pembangunan yang partisipatif, kepentingan serta dapat menjadikan masyarakat diharapkan dapat: (1) mampu masyarakat sebagai subjek pembangunan secara kritis menilai lingkungan sosial terutama masyarakat lokal, tipe dan bentuk partisipasi dimaksudkan, menurut Syahyuti (2006) antara lain: (1) Collaberation, masyarakat lokal bekerja sama dengan pihak luar untuk menentukan prioritas, dan pihak luar bertanggung jawab langsung terhadap proses Collaborators; (2) Co-learning, masyarakat lokal dan luar saling membagi pengatahuannya, untuk memperoleh saling pengertian dan bekerja sama untuk merencanakan aksi sementara pihak luar hanya memfasilitasi partners; (3) ekonomi mereka sendiri, mengidentifikasi bidang-bidang yang perlu diperbaiki, (2) menentukan visi masa depan yang ingin masyarakat wujudkan, (3) dapat berperan dalam perencanaan masa depan mareka sendiri dalam masyarakat tanpa menyerahkan kepada ahli atau kelompok berkuasa, (4) dapat menghimpun sumbersumber daya dalam masyarakat dan juga dalam lingkup anggotanya untuk merealisasi tujuan bersama, (5) dapat memperoleh pengelaman dalam Collective-action, masyarakat lokal menyusun dan melaksanakan agendanya sendiri pihak luar tidak terlibat secara penuh.

Partisipasi masyarakat dapat terwujud seiring tumbuhnya rasa percaya masyarakat kepada penyelenggara pemerintahan di daerah. Rasa percaya ini akan tumbuh apabila masyarakat memperoleh pelayanan dan kesempatan yang setara. Perbedaan perlakuan atas menyatakan, menganalisa situasi dan mengidentifikasi strategi yang tepat dan realistis untuk suatu kehidupan yang lebih baik, (6) disebabkan anggota masyarakat menjadi anggota individual yang dapat bekerja atas dasar persamaan, (7) desa dan masyarakat akan menyelesaikan tugas dan proyek swadaya karena masyarakat tidak tergantung pada bantuan dari luar dan selanjutnya akan dibangun hubungan yang erat dan integratif di antara anggota masyarakat. 
Dalam hubungannya dengan nilai-nilai luhur dan kebutuahan pelaksanaan program PNPM-Pedesaan masyarakat (Pedoman PNPM Mandiri sesuai pedoman pelaksanaannya dapat Pedesaan, 2010). dijelaskan bahwa substansi dari proses Dalam Pedoman PNPM Mandiri pemberdayaan masyarakat pada Pedesaan (2010) dijelaskan pula bahwa prinsipnya adalah memulihkan dan sasaran utama penyelenggaraan program melembagakan kembali kapital sosial ini adalah:

(modal sosial) yang dimiliki masyarakat, yakni dengan mendorong masyarakat agar mampu meningkatkan kepedulian dan kesatuan serta solidaritas sosialnya untuk bahu-membahu dan bersatu-padu menanggulangi masalah kemiskinan diwilayahnya secara mandiri dan berkelanjutan, yang bertumpuh pada nilai kebersamaan, kemasyarakatan dan pembangunan berkelanjutan (Pedoman Pelaksanaan PNMP Mandiri, 2010).

Oleh karena itu, siklus pelaksanaan program PNPM Mandiri Pedesaan adalah siklus kegiatan yang dilaksanakan 1. Terbangunnya lembaga keswadayaan masyarakat (LKM) yang terpercaya, aspiratif, representatif dan akuntabel untuk mendorong tumbuh dan berkembangnya partisipasi serta kemandirian masyarakat.

2. Tersedianya makanisme perencanaan sebagai wadah untuk mewujudkan senergi dari berbagai program penanggulangan kemiskinan yang kompherenshif dan sesuai dengan aspirasi dan kebutuhan masyarakat lokal.

Sejalan dengan peranan dan fungsi sepenuhnya oleh masyarakat melalui pendekatan partisipasi dan pemberdayaan oleh masyarakat desa setempat, sementara itu pendampingan pihak luar (Fasilitator, Fordes, Pemda dan lain-lain), hanyalah sebagai pendamping pembelajaran agar inisiatif, prakarsa, komitmen, kepedulian, motivasi, keputusan dan ihtiar dari masyarakat benar-benar berbasis pada pelaksanaan Program Nasioanal Pemberdayaan Masyarakat Pedesaan, dimana tujuan utamanya adalah menciptakan kemandirian masyarakat lokal malalui makanisme partisipasi dan pemberdayaan masyarakat lokal, di mana keberadaan PNPM-Mandiri pedesaan lebih sebagai fasilitator bukan sebagai pelaksana program pada tingkat 
operasional, konseptualisasi, perencanaan, pelaksanaan dan evaluasi dimana pada tahapan ini harus lebih diperankan keberadaan masyarakat sebagai wujud dari adanya partisipasi dan pemberdayaan masyarakat lokal, dalam hubunganan dimaksud, maka kehadiran program PNPM Mandiri pedesaan di berbagai desa selama ini telah membawa dampak positif terhadap berbagai perubahan, terutama dalam hubungannya dengan pembangunan infra strukturuk desa maupuan dalam rangka menciptakan kesadaran kolektif masyarakat desa. Berdasarkan beberapa hasil obesvasi menunjukan bahwa masyarakat lokal memiliki keinginan yang kuat terhadap tetap berlangsungnya Program Nasional Pemberdayaan Masyarakat (PNPM) Mandiri Pedesaan.

\section{METODE PENELTIAN}

\section{Pendekatan dan Model Analisis.}

Penelitian ini termasuk dalam penelitian kualitatif serta menggunakan desian diskriptif, serta lebih bersifat kajian kepustakaan yang kemudian dihubungkan dengan realitas sosial.

\section{PEMBAHASAN}

\section{Pengertian Partisipasi.}

Menurut Yogi Suprayogi Sugandi (2011), terdapat banyak defenisi yang dikemukakan para ahli tentang partisipasi, namun secara harfiah, partisipasi berarti "turut berperan dalam suatu kegiatan", "peran aktif atau pro aktif dalam suatu kegiatan" selanjutnya menurut Yogi, "Partisipasi dapat di defenisikan secara luas sebagai bentuk kerterlibatan dan keikutsertaan masyarakat secara aktif dan sukarela baik karena alasan-alasan dari dalam dirinya (interisik) maupun dari luar dirinya (ekstrinsik) dalam keseluruhan proses kegiatan yang bersangkutan. Indria Bastian (2006).

Selanjutnya dapat dikemukakan bahwa model pendekatan partisipasi dalam proses perencanaan pembangunan meliputi dua indikator utama, yaitu: Model pendekatan dalam proses atau tahapan pembangunan institusionalisasi adalah suatu model pendekatan dengan melibatkan aktor pembangunan (swasta, masyarakat, dan pemerintah sebagai mediator). Ditingkat masyarakat, keberhasilan pendekatan ini akan dirasakan oleh masyarakat dalam upaya mengorganisasi diri, meningkatkan proses 
demokrasi, meningkatkan peran serta belaka, (b) Partisipasi Informatif, disini (partisipasi) dan mendudukkan masyarakat hanya menjawab pertanyaanmasyarakat sebagai subjek pembangunan pertanyaan untuk proyek, namun tidak

\section{Partisipasi Masyarakat.}

Partisipasi merupakan komponen penting dalam pembangkitan kemandirian dan proses pemberdayaan (Craig dan May, 1995 dalam Hikmat 2004), lebih lanjut ditambahkan Hikmat (2004) bahwa pemberdayaan dan partsipasi merupakan stategi yang sangat potensial dalam rangka meningkatkan ekonomi, sosial dan tranformasi budaya. Dimana proses ini pada akhirnya akan dapat menciptakan pembangunan yang berpusat pada rakyat.

\section{Tingkatan Partisipasi.}

Menurut Prety, J. (1995) ada tujuh karakteristik tipologi partisipasi, yang berturut-turut semakin dekat kepada bentuk partispasi yang ideal, yaitu: (a) Partisipasi pasif dan manipulatif, yakni merupakan bentuk partisipasi yang paling lemah karakteristiknya adalah masyarakat menerima pemberitahuan apa yang sedang dan telah terjadi. Adanya pengumuman sepihak oleh pelaksana proyek tanpa memperhatikan tanggapan masyarakat sebagai sasaran program. Informasi yang dipertukarkan terbatas pada kalangan professional di luar kelompok sasaran berkesempatan untuk terlibat dan mempengaruhi proses keputusan, akurasi hasil tidak dibahas bersama masyarakat, (c) Partisipasi konsultatif, masyarakat berpartisipasi dengan cara berkonsulatasi, sedangkan orang luar mendengarkan serta menganalisis masalah dan cara pemecahannya.

Dalam pola ini belum ada peluang untuk pembuatan keputusan bersama di mana para professional tidak berkewajiban untuk mengajukan pandangan masyarakat (sebagai masukan) untuk ditindak lanjuti, (d) Partisipasi inisiatif, masyarakat memberikan pengorbanan dan jasa untuk memperoleh imbalan intensif berupa upah, walau tidak dilibatkan dalam proses pembelajaran atau eksperimen-eksperimen yang dilakukan. Masyarakat tidak memiliki inisiatif dalam melanjutkan kegiatan-kegitan setelah intensif dihentikan, (e) Partisipasi fungsional masyarakat membentuk kelompok sebagai bagian proyek, setelah ada keputusan utama yang disepakati. Pada tahap awal, masyarakat tergantung kepada pihak luar, tetapi secara bertahap 
kemudian menunjukan kemandiriannya, (f) Partisipasi interaktif, masyarakat berperan dalam proses analisis untuk perencanaan kegiatan dan pembentukan atau penguatan kelembagaan, pola ini cenderung melibatkan metode interdisipliner yang mencari keragaman perspektif dalam proses belajar yang tertsruktur dan sistimatis.

Masyarakat memiliki peran untuk mengontrol atas pelaksanaan keputusankeputusan mereka, sehingga memiliki andil dalam keseluruhan proses kegiatan, (g) Partisipasi mandiri, masyarakat mengambil inisiatif sendidri secara bebas (tidak dipengaruhi oleh pihak luar) untuk mengubah sistem atau nilai-nilai yang mereka junjung. Mereka mengembangkan kontak dengan lembaga-lembaga lain untuk mendapatkan bantuan dan dukungan teknis serta sumberdaya yang diperlukan, yang terpenting masyarakat juga memegang kendali atas pemanfatan sumber daya yang ada atau digunakan.

\section{Perencanaan Partisipatoris Dalam Pembangunan}

Perencanaan merupakan bagian terpenting dalam kegiatan pembangunan oleh pemerintah dan perencanaan itu adalah suatu proses atau kegiatan pembangunan yang berjalan sesuai dengan arah yang telah di tentukan, oleh karena itu tahap perencanaan menjadi pusat perhatian bagi semua tingkatan pemerintahan dalam pembangunan (Indria Bastian, 2006).

Pembangunan mengisyaratkan adanya partisipasi masyarakat. Keikutsertaan masyarakat akan menguatkan tingkat kepercayaan (akuntabilitas) dan rasa kepemilikan masyarakat terhadap program-program kerja pemerintah. Hal ini akan membuat ringan pelaksanaan pembangunan. Akibat adanya keterlibatan dalam proses perencanaan, masyarakat akan merasakan pembangunan yang lebih nyata dengan memantau pelaksanaan program-program. Dimana pelaksanaan program/kegiatan yang telah dibuat oleh pemerintah bersama-sama dengan dewan perwakilan rakyat dan masyarakat akan lebih terarah dan tepat guna.

Dalam sistem pemerintahan yang demokratis, konsep partisipasi masyarakat merupakan salah satu konsep yang sangat penting. Dimana hakikat demokrasi sebagai sistem pemerintahan yang berfokus pada rakyat sebagai pemegang kedaulatan. Selanjutnya pada lain sisi 
menurut Indirian Bastian (2006), penting yang harus disiapkan oleh mengemukakan bahwa strategi pemerintah termasuk pemerintah daerah. pembangunan yang hanya bertumpu pada Pemberdayaan Masyarakat. paradigma pertumbuhan dan pemerataan Yogi S. Sugandi (2011), Konsep telah terbukti rentan terhadap masalahmasalah sosial, menurutnya pembangunan harus disertai dengan nilai kelestarian pembangunan (Sustainible development) guna menumbuhkan self sustaining capacity dari masyarakat. Konsep ini berindikasi bahwa pembangunan harus berpusat pada manusia (people central development), strategi ini akan menghasilkan partisipasi masyarakat dalam pembangunan.

Terkait dengan perencanaan pembangunan yang partisipatoris, maka dapatlah dikemukakan bahwa perencanaan yang disusun oleh pemerintah termasuk pemerintah daerah adalah merupakan perwujudan asas desentralisasi pemerintahan, pembangunan politik dan pengelolaan pembangunan dari pusat kepada daerah. Hal ini memiliki korelasi positif dengan pelaksanaan pemerintahan di erah otonomisasi daerah dewasa ini, di mana setiap daerah dituntut untuk lebih mandiri sehingga berbagai perintisan kearah tujuan dan kesuksesan akan menjadi agenda pemberdayaan diadaptasikan dari istilah empowerment yang berkembang pertama kali di Eropa sejak abad pertengahan, terus berkembang hingga di akhir tahun 1970-an, tahun 1980-an dan awal tahun 1990-an. Kosep pemberdayaan tersebut kemudian mempengaruhi teori-teori yang berkembang belakangan. Sejalan dengan pemaknaan konsep pemberdayaan masyarakat, oleh Ife (1995) bahwa konsep pemberdayaan adalah sebagai upaya memberikan otonomi, wewenang dan kepercayaan kepada setiap individu dalam suatu organisasi, serta mendorong masyarakat untuk kreaktif agar dapat menyelesaikan tugasnya sebaik mungkin.

Di sisi lain Paul (1987) dalam Prijono dan Pranarka (1996) mengatakan bahwa pemberdayaan berarti pembagian kekuasaan yang adil sehingga meningkatkan kesadaran politik dan kekuasaan pada kelompok yang lemah serta memperbesar pengaruh mereka terhadap proses dan hasil-hasil pembangunan. Sedangkan konsep pemberdayaan menurut Friedman (1992) 
dalam hal ini pembangunan alternatif menekankan keuntungan politik melalui otonomi pengambilan keputusan untuk melindungi kepenetingan rakyat yang berlandaskan pada sumberdaya pribadi, langsung melalui partisipasi, demokrasi dan pembelajaran sosial melalui pengamatan langsung.

Jika dilihat dari proses operasionalisasinya, maka ide pemberdayaan memilki dua kecenderungan, antara lain: pertama, kecenderungan primer, yaitu kecenderungan proses yang memberikan atau mengalihkan sebagian kekuasaan, kekuatan dan kemampuan (power) kepada masyarakat atau individu menjadi lebih berdaya. Proses ini dapat dilengkapi pula dengan upaya membangun asset material guna mendukung pembangunan kemandirian oleh masyarakat; dan kedua kecenderungan sekunder, yaitu kecenderungan yang menekankan pada proses pemberian stimulisasi, mendorong dan memotivasi individu agar mempunyai kemampuan atau keberdayaan untuk menentukan apa yang menjadi pilihan hidupnya melalui proses dialog. Dua kecenderungan tersebut berada pada titik ekstrim tertentu, seolah bersebrangan, namun sering kali untuk mewujudkan kecenderungan primer harus melalui kecenderungan sekunder terlebih dahulu (Sumadiningrat, Gunawan, 2002).

Pemberdayaan masyarakat adalah sebuah konsep pembangunan ekonomi yang merangkum nilai-nilai sosial. Konsep ini mencerminkan paradigma baru pembangunan, yakni bersifat people centred, participatory, empowering and sustainable" (Chambers, 1995) konsep ini lebih luas dari hanya semata-mata memenuhi kebutuhan dasar (basic needs) atau menyediakan makanisme untuk mencegah proses pemiskinan lebih lanjut, yang belakangan lebih banyak dikembangkan sebagai upaya mencari alternatif terhadap konsep pertumbuhan di masa yang lalu. Konsep ini berkembanmg dari banyak ahli dan praktisi.

Dalam upaya pemberdayaan masyarakat dapat dilihat dari tiga sisi, (Sumadiningrat, Gunawan, 2002); yaiutu: pertama menciptakan suasana atau iklim yang memungkinkan potensi masyarakat berkembang dimana titik tolaknya adalah penganalan bahwa setiap manusia, setiap masyarakat, memiliki potensi yang dapat dikembangkan, artinya tidak ada 
masyarakat yang sama sekali tanpa daya, karena jika yang demikian akan suda punah. Pemberdayaan adalah upaya untuk membangunan daya itu, dengan mendorong, memotivasikan, dan membangkitkan kesadaran akan potensi yang dimilikinya serta berupaya untuk mengembangkannya.

$\mathrm{Ke} d u a$, memperkuat potensi atau daya yang dimiliki masyarakat (empowering). Dalam rangka ini diperlukan langkah-langkah yang positif, selain dari hanya menciptakan iklim dan suasana. Perkuatan ini meliputi langkahlangklah nyata, dan menyangkut penyediaan berbagai masukan (input), serta pembukaan akses ke dalam berbagai peluang yang akan membuat masyarakat menjadi berdaya, pemberdayaan bukan meliputi pengauatan individu anggota masyarakat, tetapi juga pranatapranatanya. Menanamkan nilai-nilai budaya modern, seperti kerja keras, hemat, keterbukaan dan pertanggungjawaban adalah bagian pokok dari upaya pemberdayaan. Demikian pula pembeharuan institusi-institusi social dan pengintegrasiannya ke dalam kegiatan pembangunan serta peran masyarakat di dalamnya.
Ke tiga, memberdayakan mengandung pula arti melindungi, dalam proses pemberdayaan, harus dicegah yang lemah menjadi bertambah lemah, oleh karena kekuranganberdayaan dalam menghadapi yang kuat, oleh karena itu, perlindungan dan pemihakan kepada yang lemah amat mendasar sifatnya dalam konsep pemberdayaan masyarakat. Melindungi tidak berarti mengisolasi atau menutup dari interaksi, karena hal itu, justru akan mengerdilkan yang kecil dan melemahkan yang lemah. Melindungi harus dilihat sebagai upaya untuk mencegah terjadinya persaingan yang tidak seimbang, serta eksploitasi yang kuat atas yang lemah. Pemberdayaan masyarakat bukan membuat masyarakat menjadi makin tergantung pada berbagai program pemberian.

\section{KESIMPULAN.}

Berdasarkan uraian latar belakang, kajian pustaka serta analisis data di atas, maka dapat disimpukan bahwa program nasional pemberdayaan masyarakat (PNPM) mandiri pedesaan sejak penerapannya telah menumbuhkembangkan kesadran kritis masyarakat local untuk secara proaktif terlibat secara kolektif dalam berbagai 
kegiatan pembangunan, adanya penguatan kapasitas masyarakat local dalam berbagai model dan pendekatan yang bertujuan untuk menjadikan masyakat sebagai pelaku utama pembangunan, konseptualisasi, perencanan, implementasi dan refleksi hasil-hasi pembangunan tidak lagi bersifat sektoral dan top dawn, tetapi lebih bersifat partisip dan battom up

\section{DAFTAR PUSTAKA}

Abe. 2005. Perencanaan Pembangunan. PT. Gunung Agung. Jakarta.

Coner. 1992. Perubahan Sosial dan Dunia Ketiga. Gadjah Masa University. Yogyakarta.

Chambers. 1995. Partcipatory Rural Appraisal. Yayasan Mitra Tani. Yogyakarta

Craig dan May. 1995. Social Capital, Civic Science and Deliberative Dialogue. Working paper. UI Press. Jakarta

Hoofsteede. 1971. Local Organization: Intermediaries in Rural
Development. Cornell University Press. Ithaca.

Idria Bastian. 2006. Sistem Perencanaan dan Penganggaran Pemerintah Daerah di Indonesia. Salemba Empat. Jakarta.

Pembangunan Daerah. 2000. Aktualisasi Otonomi dalam Pembangunan Daerah. Depdagri.

Mustopadijaja. 2007. Metode Penelitian Partsipatoris dan Upaya Pemberdayaan. Yayasan Obor. Jakarta.

Prijono dan Pranarka. 1996. Administrasi Pembangunan. UM Press. Malang

Syahyuti. 2006. Perencanaan Partisipatif di Kabupaten Maros. Program Pasca Sarjana Universitas Hasanuddin Makassar (Tidak dipublikasikan).

Yogi S. Sugandi. 2011. Admiistrasi Publik (Konsep dan Perkembangan Ilmu di Indonesia). Graha Ilmu. Yogyakart

Undang-Undang Nomor 25 Tahun 2004. Tentang Sistem Perencanaan Pembangunan Nasional (SPP)

Undang-Undang Nomor 32 Tahun 2004 Tentang Pemerintahan Daerah 